\title{
Pengaruh Penghargaan Instrinsik Terhadap Kinerja Pegawai PT. Harapan
}

\author{
${ }^{1}$ Wahyu Aulia Siregar, ${ }^{2}$ Efridar Hadisyah Putra Hsb, ${ }^{3}$ Dewi Zahra, ${ }^{4}$ Muhammad Hamdany Lubis \\ ${ }^{1-4}$ Program Magister Manajemen, Fakultas Ekonomi, Universitas Islam Sumatera Utara
}

Article history

Received: 12 Jan 2021

Revised: 20 Feb 2021

Accepted: 02 Mar 2021

*Corresponding Author:

Wahyu Aulia Siregar

Program Studi Magister

Manajemen, Fakultas

Ekonomi, Universitas Islam

Sumatera Utara

Email:

wahyuauliasrg@gmail.co $\underline{\mathrm{m}}$

\begin{abstract}
Abstrak: Penelitian ini akan melihat pengaruh penghargaan instrinsik terhadap kinerja pegawai PT. Harapan Bersama Lestari. Adapun tujuan dari penelitian ini yaitu untuk mengetahui pengaruh penghargaan instrinsik terhadap kinerja pegawai. Metode yang digunakan dalam penelitian ini adalah dengan pendekatan survey melalui observasi, wawancara, pembagian kuesioner dan studi dokumentasi. Metode analisis data yang digunakan adalah analisis regresi linier berganda. Populasi dalam penelitian ini adalah sebagian pegawai PT. Harapan Bersama Lestari Medan yang berjumlah 38 pegawai. Hasil menunjukkan bahwa secara simultan variabel penghargaan instrinsik berpengaruh signifikan terhadap kinerja. Selain itu, secara parsial variabel komunikasi tidak berpengaruh secara signifikan terhadap kinerja pegawai. Pada hasil penelitian selanjutnya menunjukkan bahwa besarnya nilai koefisien korelasi berganda $(\mathrm{R})$ adalah 0,718 , hal ini menunjukkan bahwa besarnya pengaruh variabel penghargaan instrinsik dengan kinerja pegawai adalah sebesar 0,718 atau $(71,8 \%)$
\end{abstract}

Kata Kunci : Gaya Kepemimpinan, Penghargaan Instrinsik, Kinerja Pegawai

\section{PENDAHULUAN}

Saat merencanakan, mengelola dan mengendalikan sumber daya manusia (SDM) dibutuhkan suatu alat manajerial yang disebut manajemen sumber daya manusia (MSDM). Dalam prakteknya, PT. Harapan Bersama Lestari Medan tergolong perusahaan yang memiliki komitmen untuk terus melakukan pengembangan. Organisasi dan struktur kerja terukur dalam rangka pemenuhan pelayanan dan keamanan yang mutlak dan tidak dapat ditawartawar. Membangun kebersamaan antar pemegang saham, direksi dan pegawai untuk memeroleh kesejahteraan bersama dengan meninjau kinerja pegawainya. Karena fokus MSDM terletak pada upaya mengelola SDM di dalam dinamika interaksi antara organisasi pekerja yang memiliki kepentingan berbeda (Priyono, 2010).

Kemungkinan yang memengaruhi kinerja pegawai menurut peneliti adalah penghargaan intrinsik yang diberikan PT. Harapan Bersama Lestari Medan untuk pegawaipegawainya. Penghargaan intrinsik sebagai penghargaan yang diatur sendiri oleh seseorang. Pemberian penghargaan intrinsik pada setiap orang harus disesuaikan dengan hak dan kewajibannya. Hal itu menyediakan perasaan puas atau terima kasih dan sering kali perasaan bangga akan pekerjaan yang dilakukan dengan baik (Wibowo, 2012). Pemimpin PT. Harapan Bersama Lestari telah memberikan penghargaan yang layak pada pegawai-pegawainya seperti mendaftarkan seluruh pegawainya pada BPJS Ketenagakerjaan, bonus, interaksi yang manusiawi dan lain sebagainya. Namun tetap saja masih ada pegawai yang kurang maksimal dalam melaksanakan tugasnya. Oleh karena itu peneliti melihat kemungkinan ada kekurangan dalam penghargaan intrinsik yang diberikan oleh pemimpin PT. Harapan Bersama Lestari Medan yang menyebabkan masih ada saja pegawai yang kurang maksimal dalam melaksanakan tugas-tugasnya.

Suatu penghargaan intrinsik didefinisikan sebagai penghargaan yang diatur sendiri 
oleh seseorang. Hal tersebut menyediakan perasaan puas atau terima kasih dan sering kali perasaan bangga akan pekerjaan yang dilakukan dengan baik. Beberapa indikator penghargaan intrinsic antara lain penyelesaian (Completion), pencapaian (Achievement), otonomi (Autonomy), dan pertumbuhan Pribadi (Personal Growth). Dengan mengembangkan kemampuan, seseorang mampu untuk memaksimalkan atau setidaknya memuaskan potensi keterampilan. Sebagian orang sering kali merasa tidak puas dengan pekerjaan dan organisasi mereka jika tidak diizinkan atau didorong untuk mengembangkan keterampilan mereka (Donelly, 1984). Karena penting untuk perusaan dalam menjaga kinerja pegawai agar pegawai dalam melaksanakan keseluruhan tugas-tugas yang menjadi tanggung-jawabnya (Fattah, 2017).

\section{METODOLOGI PENELITIAN}

Metode yang digunakan dalam penelitian ini adalah kuantitatif deskriptif dengan pendekatan survey melalui observasi, wawancara, pembagian kuesioner dan studi dokumentasi (Sugiyono, 2014). Metode analisis data yang digunakan adalah analisis regresi linier berganda. Objek dan populasi dalam penelitian ini adalah sebagian personil di PT. Harapan Bersama Lestari Medan yang berjumlah 38 orang. Penelitian ini tidak menggunakan penelitian sampel tetapi menggunakan penelitian populasi karena jumlah populasi kurang dari 100 orang, oleh karena itu penelitian ini mengambil seluruh populasi yang ada pada Tabel 1. yang berjumlah 38 orang.

Tabel 1. Populasi Penelitian

\begin{tabular}{|c|l|c|}
\hline No & \multicolumn{1}{|c|}{ Bagian } & Populasi (orang) \\
\hline 1 & Direktur Utama & 1 \\
2 & Direktur Operasi & 1 \\
3 & Manager Operasi & 1 \\
4 & ST. Operasi & 1 \\
5 & ST. Administrasi & 1 \\
6 & ST. Pajak & 1 \\
7 & Koordinator Pelayanan Umum & 1 \\
8 & Pelayanan Umum & 2 \\
9 & Supervisor KNO & 3 \\
10 & Pelaksana KNO & 12 \\
11 & Pelaksana BIJB & 4 \\
12 & Pelaksana FL. Tobing & 3 \\
13 & Pelaksana Banyu Wangi & 2 \\
14 & Pelaksana Batam & 5 \\
\hline & Total & 38 \\
\hline
\end{tabular}

Sumber: PT. Harapan Bersama Lestari Medan (2020) dan diolah oleh peneliti (2020) 


\section{Teknik Pengumpulan Data}

Teknik pengumpulan data yang digunakan dalam penelitian ini adalah :

1. Observasi dilakukan oleh peneliti dengan cara pengamatan dan pencatatan mengenai pelaksanaan kegiatan pada PT. Harapan Bersama Lestari

2. Wawancara (Interview) yang dilakukan dengan pihak-pihak yang berhak dan berwenang memberikan informasi dan data di PT. Harapan Bersama Lestari sehubungan dengan penelitian ini

3. Angket (Questionnaire) yang diberikan kepada seluruh personil PT. Harapan Bersama Lestari sebagai responden penelitian

4. Studi Dokumentasi dilakukan dengan mengumpulkan dan mempelajari dokumendokumen yang mendukung penelitian ini, seperti jumlah pegawai, deskripsi kerja karyawan, tingkat pendidikan, dan lain-lain yang diperoleh dari PT. Harapan Bersama Lestari.

\section{Definisi Operasional Variabel}

\section{Jenis variabel}

Penghargaan Intrinsik

Penghargaan intrinsik sebagai penghargaan yang diatur sendiri oleh seseorang. Hal itu menyediakan perasaan puas atau terima kasih dan sering kali perasaan bangga akan pekerjaan yang dilakukan dengan baik. (Wibowo, 2012).

\section{Indikator}

1. Penyelesaian Pekerjaan Kemampuan

2. Pencapaian Prestasi

3. Otonomi pengembangan Pribadi Individu.

\section{Uji Instrumen Penelitian}

\section{Uji Validitas}

Penjelasan tentang validitas sampai di sini dapat disimpulkan bahwa dalam penelitian kuantitatif, validitas internal berarti tercapainya aspek kebenaran atau the truth value hasil penelitiannya sehingga dapat dipercaya, sedangkan dalam pengertian penelitian naturalistic validitas internal mengacu pada ada tidaknya kredibilitas. Sedangkan validitas eksternal, dalam penelitian kuantitatif berarti berkenaan dengan aspek generalisasi atau tingkat aplikasi sementara dalam penelitian kualitatif berarti adanya kecocokan atau kesesuaian atau dapat diterapkan.

\section{Uji Reliabilitas}

Dalam penelitian kuantitatif reliabilitas berkenaan dengan apakah penelitian itu dapat diulangi atau direplikasi oleh peneliti lain dan menemukan hasil yang sama bila peneliti menggunakan metode yang sama. Jadi reliabilitas menunjukkan adanya konsistensi.

\section{Teknik Analisis Data}

Analisis data yang akan dipergunakan untuk menganalisis penelitian ini adalah 
analisis regresi berganda untuk menguji variable bebas (gaya kepemimpinan demokratis) terhadap variable terikat (kinerja pegawai).

\section{Uji F (Uji secara Simultan)}

Uji F dilakukan untuk melihat secara simultan (bersama-sama) apakah ada pengaruh dari variabel bebas (gaya kepemimpinan demokrasi) terhadap variable terikat (kinerja pegawai). Model hipotesis yang digunakan dalam uji $\mathrm{F}$ ini adalah :

$\mathrm{H}_{0}: \mathrm{b}_{1} \mathrm{~b}_{2} \mathrm{~b}_{3}=0$ Tidak adanya pengaruh antara gaya kepemimpinan demokratis, komunikasi, dan penghargaan intrinsik terhadap kinerja pegawai

$\mathrm{H}_{\mathrm{a}}: \mathrm{b}_{1} \mathrm{~b}_{2} \mathrm{~b}_{3} \neq 0$ Adanya pengaruh gaya kepemimpinan demokratis, komunikasi, dan penghargaan intrinsik terhadap kinerja pegawai

\section{Uji t (Uji Secara Parsial)}

Uji t bertujuan untuk melihat secara parsial apakah ada pengaruh dari variabel bebas (gaya kepemimpinan demokratis) terhadap variabel terikat (kinerja pegawai) pada PT. Harapan Bersama Lestari Medan. Model Hipotesis yang digunakan dalam uji ini adalah :

$\mathrm{H}_{0}: \mathrm{b} 1=0 \quad$ gaya kepemimpinan demokratis, komunikasi dan penghargaan intrinsik secara parsial tidak berpengaruh terhadap kinerja pegawai PT. Harapan Bersama Lestari

$\mathrm{H}_{\mathrm{a}}: \mathrm{b} 1 \neq 0 \quad$ (gaya kepemimpinan demokratis, komunikasi dan penghargaan intrinsik secara parsial berpengaruh terhadap kinerja pegawai PT. Harapan Bersama Lestari.

\section{HASIL DAN PEMBAHASAN}

\section{Uji Validitas dan Reliabilitas}

\section{Uji Validitas}

Pada pengujian, akan diuji sejumlah 38 responden dengan kuesioner untuk menangkap data dalam penelitian. Pengujian ini terdiri dari variable bebas (prediktor) yaitu gaya kepemimpinan demokratis $\left(\mathrm{X}_{1}\right)$, komunikasi $\left(\mathrm{X}_{2}\right)$ dan penghargaan intrinsik $\left(\mathrm{X}_{3}\right)$, dan variable bergantung yaitu kinerja pegawai(Y).

Untuk mengukur validitas alat ukur diperlukan kriteria sebagai alat pembanding. Dalam penelitian ini digunakan pembanding dari dalam, untuk menguji alat ukur yang berupa angket digunakan korelasi antara tiap butir angket dengan total butir angket (Nawari, 2010).

Angka korelasi $\mathrm{r}$ hitung yang diperoleh kemudian dibandingkan dengan angka korelasi $\mathrm{r}$ yang terdapat pada tabel dengan tingkat kesalahan $5 \%$ dan jumlah $\mathrm{n}=38$ maka diperoleh $r$ tabel $=0,3202$. Jika $r$ hitung positif, serta $r$ hitung $>r$ tabel, maka butir instrument tersebut valid. Jika $r$ hitung tidak positif dan $r$ hitung $<r$ tabel maka butir instrument tersebut tidak valid.

Tabel 2. Hasil Pengujian Validitas Instrumen Variabel Penghargaan Intrinsik $\left(\mathrm{X}_{3}\right)$

\begin{tabular}{|c|l|c|c|c|}
\hline No. & Instrumen Variabel $\left(\mathbf{X}_{\mathbf{3}}\right)$ & $\mathbf{r}$ hitung & r tabel & Keterangan \\
\hline 1 & $\begin{array}{l}\text { Penyelesaian Pekerjaan } \\
\text { Kemampuan }\end{array}$ & 0,828 & \multirow{2}{*}{0,3202} & Valid \\
\cline { 2 - 3 } 2 & Pencapaian Prestasi & 0,876 & & Valid \\
\hline
\end{tabular}




\begin{tabular}{|c|lc|c|c|c|}
\hline 3 & Otonomi & 0,725 & & Valid \\
\hline 4 & $\begin{array}{l}\text { Pengembangan } \\
\text { Individu }\end{array}$ & Pribadi & 0,834 & & Valid \\
\hline
\end{tabular}

Berdasarkan uji validitas instrument variabel Penghargaan Intrinsik $\left(\mathrm{X}_{3}\right)$ pada tabel 2, maka hasilnya dapat dijelaskan sebagai berikut:

1. $r$ hitung instrumen "penyelesaian pekerjaan kemampuan" adalah $0,828>0,3202$ artinya instrumen ini memenuhi syarat validitas

2. $r$ hitung instrument "pencapaian prestasi" adalah $0,876>0,3202$ artinya instrumen ini memenuhi syarat validitas

3. $\mathrm{r}$ hitung instrument "otonomi" adalah 0,725 > 0,3202 artinya instrumen ini memenuhi syarat validitas

4. $\mathrm{r}$ hitung instrument "pengembangan pribadi individu" adalah 0,834 >0,3202 artinya instrumen ini memenuhi syarat validitas.

Tabel 3. Hasil Pengujian Validitas Instrumen Variabel Kinerja Pegawai (Y)

\begin{tabular}{|c|l|c|c|c|}
\hline No. & \multicolumn{1}{|c|}{$\begin{array}{c}\text { Instrumen } \\
\text { Variabel (Y) }\end{array}$} & r hitung & r tabel & Keterangan \\
\hline 1 & $\begin{array}{l}\text { Kuantitas hasil } \\
\text { kerja }\end{array}$ & 0,843 & & Valid \\
\hline 2 & Kualitas hasil kerja & 0,871 & \multirow{5}{*}{0,3202} & Valid \\
\hline 3 & Disiplin kerja & 0,868 & Valid \\
\hline 4 & Ketelitian kerja & 0,891 & & Valid \\
\hline 5 & Kejujuran kerja & 0,885 & & Valid \\
\hline 6 & Kreatifitas kerja & 0,818 & & Valid \\
& & &
\end{tabular}

Berdasarkan uji validitas instrument variabel Kinerja Pegawai (Y) pada tabel 3, maka hasilnya dapat dijelaskan sebagai berikut:

1. r hitung instrumen "kuantitas hasil kerja" adalah 0,843>0,3202 artinya instrumen ini memenuhi syarat validitas

2. r hitung instrument "kualitas hasil kerja" adalah 0,871 >0,3202 artinya instrumen ini memenuhi syarat validitas

3. r hitung instrument "disiplin kerja" adalah 0,868>0,3202 artinya instrumen ini memenuhi syarat validitas

4. r hitung instrument "ketelitian kerja" adalah 0,891>0,3202 artinya instrumen ini memenuhi syarat validitas

5. $\mathrm{r}$ hitung instrument "kejujuran kerja" adalah 0,885 > 0,3202 artinya instrumen ini memenuhi syarat validitas

6. $\mathrm{r}$ hitung instrument "kreatifitas kerja" adalah 0,818>0,3202 artinya instrumen ini memenuhi syarat validitas. 


\section{Uji Reliabilitas}

Tabel 4. Uji Reliabilitas Variabel

\begin{tabular}{|c|c|c|}
\hline Variabel & Koefisien Alpha & Keputusan \\
\hline $\mathrm{X} 3$ & 0,826 & Reliabel \\
\hline
\end{tabular}

Berdasarkan nilai reliabilitas instrument pada tabel 4, maka dapat disimpulkan bahwa semua instrument memenuhi syarat reliabilitas, hal ini berarti hasil pengukuran dari item persyaratan untuk penelitian ini relatif stabil.

\section{Analisis Regresi Linier Berganda}

Tabel 5. Hasil Analisis Regresi Linier

\begin{tabular}{|c|c|c|c|c|c|c|c|}
\hline \multicolumn{8}{|c|}{ Coefficients $^{\mathrm{a}}$} \\
\hline \multirow[b]{2}{*}{ Mode } & & & \multicolumn{2}{|c|}{ Unstandardized Coefficients } & \multirow{2}{*}{$\begin{array}{c}\begin{array}{c}\text { Standardized } \\
\text { Coefficients }\end{array} \\
\text { Beta }\end{array}$} & \multirow[b]{2}{*}{$t$} & \multirow[b]{2}{*}{ Sig. } \\
\hline & & & $B$ & Std. Error & & & \\
\hline \multirow[t]{4}{*}{1} & \multirow{2}{*}{\multicolumn{2}{|c|}{$\begin{array}{l}\text { (Constant) } \\
\text { Gaya Kepemimpinan } \\
\text { Demokratis(X1) }\end{array}$}} & 1.465 & 4.060 & & .361 & \\
\hline & & & -.128 & .197 & -.10 & -.652 & \\
\hline & \multicolumn{2}{|c|}{ Komunikasi $(X 2)$} & .461 & .252 & .35 & 1.832 & \\
\hline & \multicolumn{2}{|c|}{$\begin{array}{l}\text { Penghargaan Intrinsik } \\
(\times 3)\end{array}$} & .794 & .278 & .49 & 2.855 & \\
\hline \multicolumn{8}{|c|}{ a Denendent Variable: Kineria Pecaawai $M$} \\
\hline & \multicolumn{7}{|c|}{ Model Summary } \\
\hline & Model & $\mathrm{R}$ & $\mathrm{R}$ Square & $\begin{array}{r}\text { Adjus } \\
\text { Sq }\end{array}$ & $\begin{array}{l}\text { sted } R \\
\text { uare }\end{array}$ & $\begin{array}{l}\text { Std. Error } \\
\text { the Estim }\end{array}$ & \\
\hline & 1 & $.718^{\mathrm{a}}$ & .516 & & .473 & 3.40 & \\
\hline
\end{tabular}

Berdasarkan hasil analisis di tabel 5, maka dapat diperoleh model regresi linier berganda sebagai berikut:

$\mathrm{Y}=1,465-0,128 \mathrm{X} 1+0,461 \mathrm{X} 2+0,794 \mathrm{X} 3+\mathrm{e}$

a. Nilai konstanta sebesar 1,465 menunjukkan bahwa apabila variable independen konstan atau sama dengan nol maka kinerja pegawai sebesar 1,465

b. Besarnya koefisian regresi $\beta_{3}$ adalah 0,794 , hal ini menunjukkan bahwa dengan meningkatnya variabel penghargaan intrinsik maka akan meningkatkan kinerja pegawai sebesar 0,794.

c. Besarnya nilai koefisien korelasi berganda (R) adalah 0,718 , hal ini menunjukkan bahwa besarnya pengaruh variable gaya kepemimpinan demokratis, komunikasi dan penghargaan intrinsik dengan kinerja pegawai adalah sebesar 0,718.

d. Besarnya nilai koefisien determinasi $\left(\mathrm{R}^{2}\right)$ adalah 0,516 , hal ini menunjukkan bahwa besarnya pengaruh variabel gaya kepemimpinan demokratis, komunikasi dan penghargaan intrinsik dengan kinerja pegawai sebesar 0,516 atau $(51,6 \%)$ dan sisanya sebesar 0,484 atau (48,4 \%) dipengaruhi oleh faktor atau variabel lain yang tidak dimasukkan dalam model penelitian. 


\section{KESIMPULAN}

Berdasarkan hasil analisis dan pembahasan penelitian ini maka dapat diambil kesimpulan bahwa komunikasi secara langsung berpengaruh positif dan signifikan terhadap variable kinerja pegawai PT. Harapan Bersama Lestari Medan dengan nilai t hitung sebesar 2,855 lebih besar daripada t tabel sebesar 2,0322 $(2,855>2,0322)$ dan nilai sig.t $=0,007$ lebih kecil dari $\alpha=5 \%(0,007<0,05)$. Selain itu, penghargaan instrinsik secara simultan berpengaruh positif dan signifikan terhadap kinerja pegawai pada PT. Harapan Bersama Lestari Medan dengan nilai F hitung sebesar 12,089 dengan tingkat Sig. F sebesar 0. Nilai F hitung tersebut lebih besar dari F tabel yang sebesar 3,28 $(12,089>3,28)$ dan nilai Sig F lebih kecil dari nilai $\alpha=5 \%(0<0,05)$.

\section{DAFTAR PUSTAKA}

Caropeboka, R.M. 2017. Konsep dan Aplikasi Ilmu Komunikasi. Yogyakarta.: Penerbit ANDI. Hal 5-7, 19.

Fattah, Hussein. 2017. Kepuasan Kerja dan Kinerja Pegawai. Yogyakarta : Elmatera

Gibson, J.L, Ivancevich, J.M dan Donelly, J.Jr.1984. "Organisasi dan Manajemen”: Perilaku, Struktur dan Proses. Edisi Keempat. Jakarta : Penerbit Erlangga.

Nawari. 2010. Analisis Regresi dengan MS Excel 2007 dan SPSS 17. Jakarta: Elex Media Komputindo.

Priyono. 2010. Manajemen Sumber Daya Manusia. Zifatama Publisher. Sidoarjo. Hal 4 \& 187.

Sugiyono. 2014. Metode Penelitian Bisnis. Bandung: Alfabeta.

Wibowo. 2012. Manajemen Kinerja. Jakarta: Rajawali Pers. 
